\title{
EDitorial
}

\section{Curriculum Matters 10 years on: A window on curriculum}

\author{
Jane Abbiss
}

The first issue of Curriculum Matters was published 10 years ago. In this tenth edition, it is interesting to look back on curriculum developments and debates that have been the focus of articles published in the journal over the decade, and to point towards current and emerging debates. Curriculum Matters provides a window on concerns and interests relating to curriculum, albeit a partial view through a particular window.

The genesis of Curriculum Matters was the interest in and debate about curriculum that accompanied the review of the Aotearoa New Zealand national curriculum in the first decade of the millennium (Begg, 2005). Edited by Andy Begg, articles in the inaugural edition of the journal focused on a range of themes, which included: national curriculum development (for early childhood and compulsory schooling); literacy and numeracy teaching and learning; curriculum theory and philosophy for the knowledge age and ethically oriented curricula; citizenship education; curriculum integration; and teacher and learner experiences in particular subject or learning contexts. These and overlapping themes have been explored across subsequent editions of the journal, suggesting that there is continuity in points of interest and that there are ongoing challenges relating to curriculum and curriculum issues.

In her editorial for the fifth edition of Curriculum Matters, Carol Mutch (2009) highlighted the newness of the field of curriculum studies, a field that is characterised by a growing tradition of curriculum theorising as an accompaniment and foil for largely pragmatic curriculum interests. She drew attention to different models for thinking about different layers of curriculum policy, design, and implementation and invited readers to consider what, how and for whom curriculum is developed. In looking 


\section{Editorial}

back across previous editions of the journal, the questions of "what?", "how?" and "for whom?" have been explored in a range of contexts. Different authors have examined

- the nature and moral purpose of curriculum (for example, relating to ethically oriented curriculum, citizenship education, future-focused education, inclusion, diversity and normative curriculum practices)

- the management and organisation of curriculum (including the politics of, and influences on, curriculum development, particular national curriculum developments, teachers' understandings and curriculum implementation and decision making in schools)

- pedagogy, teaching and learning in relation to curriculum aims, such as developing key competencies, literacy and numeracy, disciplinary thinking, ethical knowing and culturally responsive practice, generally and in particular subject contexts (such as mathematics, health, English)

- curriculum debates in relation to different education sectors (early childhood, compulsory schooling, tertiary).

A possibly surprisingly small number of articles relating to assessment is accounted for by the formation of a sister and complementary publication called Assessment Matters, first published in 2009. Curriculum Matters, then, has provided a platform for the survey of a broad range of curriculum issues, particularly in relation to the schooling sector, the context for the largest number and range of articles.

The content of the journal can also be seen to reflect changing international and national political and policy contexts. Internationally, global trends in respect of neoliberal education policies have been seen by educational theorists and researchers to play out in things such as the commodification of education and competition between schools, standardised testing regimes, and a focus on international performance markers and rankings (Corbett, 2008; Olssen, Codd \& O'Neill, 2004; Peters, 2002). Biesta and Priestly (2013) argue that curriculum has increasingly become the business of national governments and supra-national organisations, especially through assessment structures, such as PISA, which is an Organisation for Economic Cooperation and Development (OECD) programme for student 
assessment and international comparison of student performance. In recent years in Aotearoa New Zealand, governments have looked to PISA results as a marker of national educational success, and have seen slipping PISA rankings as a source of concern. National standardised assessment regimes exist in the National Certificate of Education Achievement (NCEA) for secondary level students and the more recently introduced National Standards for primary students. Education policies have also focused on and encouraged the development of knowledge societies, 21st century learning and "modern" schooling environments and pedagogies (which may simultaneously reflect and sustain neo-liberal, technological, socially transformative and other discourses) (Abbiss, 2013). These global policy developments set the context for curriculum development at national and local levels and have implications for how curriculum may be developed by teachers and experienced by students.

Broad global trends, and the ways in which they have been given effect at a national level, have provided stimulus and background for a range of articles in Curriculum Matters. Articles have taken the form of explicit responses to policy shifts and impacts, such as: the impact of scientific management on the focus of teaching and learning early in childhood centres (Hannigan, 2013) and the study of history in secondary schools (Fountain, 2008), a questioning of the nature of learning and efficacy of teaching practices for 21 st-century learners (see for example Hipkins, 2005; Tallon, 2013), and broad attention to issues of equity and inclusion in curriculum (for example Carpenter \& Lee, 2010; Edwards, Lambert $\&$ Tauroa, 2007; Rutherford, 2009; Samu, 2011). While the spark for the establishment of the journal ten years ago and the focus of articles in early editions may have been the review of a particular national curriculum in Aotearoa New Zealand, the interests and concerns expressed through articles in Curriculum Matters over the decade reflect broad interests in relation to curriculum.

It is perhaps axiomatic to state that curriculum is contestable. What is notable and important to examine, however, is the nature of that contestability, the shifting nature of concerns and the emerging tensions relating to curriculum. In a survey of national curriculum developments in selected, developed English-speaking countries, including Aotearoa New 


\section{Editorial}

Zealand, Aitken and Sinnema (2013) highlight trends of contestability and commonality in curriculum. They see contestability as stemming from the co-existence of different goals for educational reform and the use of curriculum as a mechanism of reform. Commonalities relate to curriculum elements that seem to be similar across newly developed curricula in different countries, including a move beyond content and skills to competencies for 21 st-century learners, an attention to pedagogy and the importance of teacher agency, and a reduction in prescription and increase in school autonomy relating to curriculum development. Biesta and Priestley (2013) argue that there are different forces steering curriculum in different ways, particularly in a Scottish context but also more broadly. These can be generally described as a tension between a return to a child and student-centred approach, which tends to emphasise democratic concerns and the role of teachers as curriculum designers, and increased centralised control, which tends to emphasise economic concerns, focus on a narrow range of aims and measurable outcomes and give policy makers a tighter grasp on curriculum. Curriculum and assessment matters are thus closely intertwined. In their view, "it remains important for all those involved in the theory and practice of curriculum to be aware of the possibilities as well as the tensions and the threats" (p. 234) stemming from these different forces.

Curriculum research, then, has an important current and future role in illuminating emerging curriculum tensions and what curriculum makes possible. This implies attention to particular curriculum concerns and to broader policy and political contexts, placing the particular in context and exploring broader tensions through examples of the particular. Drawing on the idea of curriculum as 'social facts', Young (2014) contends that "curriculum is never reducible to the acts, beliefs and motivations of individuals: it is a structure that constrains not only the activities of those involved-primarily teachers and students, but also those who design curricula or attempt to achieve certain goals with them" (p. 7). Curriculum sets limits at the same time as it enables and makes some things possible to learn.

Consideration, then, of international curriculum tensions and the role of curriculum highlights the importance of seeing curriculum developments 
within wider political and policy contexts. Curriculum Matters has been a vehicle for dissemination of a wide range of curriculum-related research and thinking relating to curriculum as a field of practice and research. It provides a forum for ongoing engagement with the possibilities and tensions inherent in curriculum development and practice. What will be interesting to see is whether and how articles in the journal reflect and respond to global trends and policy agendas over the next decade and what view of curriculum they will provide 10 years on.

\section{This collection}

In the introductory paragraph for this editorial, I used the metaphor of a view through a window to describe the role of Curriculum Matters in highlighting and focusing attention on curriculum related interests and challenges. A new and particular feature of the journal is the inclusion of a special section, comprising a compilation of international articles on a particular theme. The theme for this edition focuses on metaphor as an aid to understanding (providing ways of viewing) educational phenomena. This special section is an innovation that marks this tenth edition of Curriculum Matters.

As a whole the articles in this collection challenge readers to consider the different ways that curriculum policy, official curriculum documents and features of particular subject curricula may be understood. Ideas about what could and should be taught, and how learners could and should engage with curriculum elements, are contestable and negotiated in practice. These articles invite debate around the contentious nature of curriculum; the nature of knowledge, what counts as valued knowledge, and how we might know or understand curriculum processes and contexts; and the purpose and nature of teaching and learning in compulsory schooling and tertiary settings and in specific learning area or subject contexts.

The articles are presented in two sections. The first section is a collection of articles that reflect broad curriculum interests and foci. The second section forms the special section relating to the use of a metaphor.

The opening article by Jennifer Charteris is based in poststructural theory and draws on empirical research in a Year 9 English class. 


\section{Editorial}

It promotes an understanding of the development of key competencies that emphasises student subjectivity and reconceptualises the idea of learner agency. Key competencies are understood not as something that are acquired by learners and then transferred by them from one situation to another, but as performative capabilities that learners project and enact as they shift subjectivities across different discourses-identified as lifeworld, subject, and classroom discourses. Going beyond the article, readers may be challenged to think about how the development of key competencies by learners may be recognised and evidenced, in English and in other subject contexts.

The nature of specialised knowledge, specifically the changing nature of musical knowledge and the types of knowledge valued by music teachers, is the focus of research reported in the article by Graham McPhail. What musical knowledge should be taught, and how, are debatable points. McPhail highlights tensions that exist between different forms of knowledge, informal and disciplinary, and between participatory pedagogical approaches that legitimate the interests of knowers and approaches that emphasise acquisition of fundamental skills and foundational musical knowledge. Music teachers are shown to negotiate the breadth of the music field, a crowded curriculum, NCEA assessment requirements, student-centred pedagogical ideals and notions of relevance as they make curriculum decisions. This is a dynamic and complex process.

Different concepts may be prominent in curriculum documents and policy at different historical junctures. Alexis Siteine examines how the concept of "identity" has been included in the official curriculum and how the nature and use of this concept has shifted over time. She argues that there has been a movement in curriculum discourse towards process and away from subject knowledge. Identity development has come to be an important goal, and the curriculum a tool for shaping positive learner identities and legitimating learners' experiences. This focus on the process of identity development is seen as problematic and as having potentially unintended consequences, particularly for marginalised groups, if it displaces subject knowledge in the curriculum. Both Siteine and McPhail articles highlight the contestability of knowledge in curriculum and the debate around the position and importance of subject or disciplinary knowledge. 
Also interested in exploring conceptual understanding in curriculum, Ros Sullivan examines the changing meanings and understandings of "safety" in relation to education outside the classroom policy. She describes etymological changes and traces historical shifts in meaning relating to safety in curriculum policy. Policy shifts reflect community concerns and have implications for educational practice in primary school contexts. It is argued that safe practice outside the classroom has become an important consideration for primary teachers, but Sullivan advocates for a more holistic view of safety in future.

Focusing on the transition of students from secondary school to tertiary (university) education, Lisa Emerson, Ken Kilpin and Angela Feekery explore academic literacy development and the disconnection between secondary and tertiary sectors. They argue for reconceptualising NCEA as a flexible model and for the use of a combination of models to support academic literacy development for students who are transitioning from secondary school to university. Readers may be drawn to consider the role of schooling and secondary teachers in preparing students for independent academic work at university, and the responsibility of university academics to themselves understand schooling and to scaffold learning and support independent study skills for students transitioning from school to university.

The seven articles in the special section provide an international collection that focuses attention on use of metaphor as a way of understanding school students', teachers' and initial teacher educators' beliefs, understandings and experiences in a variety of curriculum and education contexts. Different metaphors are revealed as representations of students' and teachers' lived experiences. Particular metaphors are intentionally used as interpretative tools and to aid communication by researchers and teachers, such as the metaphors of food preparation and bridge construction. These articles, as a collection, invite consideration and debate about the affordances, limitations and challenges in working with metaphor to support teaching and learning in a range of contexts and as an aid to educational research.

Two of the contributions relate to the use of metaphor in initial teacher education, within specific programmes and courses in an Aotearoa New 


\section{Editorial}

Zealand university, to aid pre-service teacher learning and development. Merilyn Taylor and Judy Bailey investigate the use of metaphors as boundary objects that support pre-service teachers to explore their beliefs about mathematics, and in doing so to gain appreciation of how others' beliefs about and experiences of mathematics may not be the same as their own. The intentional use of an extended food preparation metaphor to aid pre-service teachers' understanding of pedagogy and pre-service teacher development is the focus of the article by Noeline Wright. Both articles are grounded in teacher educators' work.

Another of the articles in the section focuses attention on the limitations of metaphors. In considering the use of metaphors to aid scientific understanding in relation to evolution, Martie Sanders presents a cautionary note about the use of particular metaphors. Threats of a linguistic nature are seen to have the potential to sustain scientific misunderstanding. Grounded in metaphor theory and research, including analysis of South African junior natural science textbooks, Sanders provides a warning about risk terms that may sustain misconceptions about evolution.

Metaphor is used by several of the contributors to explore the lived experiences and understandings of students and educators in different educational contexts. Grounded in research conducted in England's Further Education (FE) sector, Ursula Edgington explores the use of metaphor to articulate FE teachers' personal meanings of space and performativity in observations of their lessons. The focus is on tertiary educators' lived experiences and meaning making. Also relating to the tertiary sector, but based in an Australian initial teacher education context, Jill Willis examines the use of feedback loop metaphors to support assessment development within an initial teacher education course. The metaphor of feedback loops as a generative dance was used within the course to support tutor and student teacher engagement in assessment for learning processes. In an Australian schooling and research context, Susan Groundwater-Smith, Eve Mayes and Kadek Arya-Pinatyh use metaphor as an analytical and interpretive research tool, in relation to a "students as co-researchers" school-based project. An extended bridge metaphor is used to represent co-researcher experiences in the project 
and investigate challenges encountered by co-researchers, to explore the nature of teacher-student relationships in school and to envision different forms of teacher-student relationships. In the article that rounds off the collection, Susan Sandretto explores a group of Aotearoa New Zealand literacy teachers' constructions of literacy and literacy metaphors, arguing that researchers, teacher educators and teachers need to make explicit their metaphors of literacy and engage in dialogue about new ways of thinking about literacy and the types of metaphors that may augment current understandings.

Together, the articles in the special section invite readers to consider the power, role and limitations of the use of metaphor in constructing understanding and communicating ideas, within different curriculum and educational contexts and as an aid to educational research. Particular metaphors are used and revealed in the examination of educational phenomena and processes, such as early years and school students learning experiences and processes of learning to teach. As noted in the Introduction for the special section, readers are invited to engage with the metaphors that the authors use and to consider their efficacy and the nature of their power in facilitating understanding. The special section provides stimulus for ongoing examination of the use of metaphor as an aid to understanding curriculum-related experiences, teaching and learning.

The collection of articles in this edition continues the engagement with a broad range of curriculum issues-a hallmark of Curriculum Matters.

\section{References}

Abbiss, J. (2013). Social sciences and ' $21^{\text {st }}$ century education' in schools: Opportunities and challenges. New Zealand Journal of Education Studies, 48(2), 5-18.

Aitken, G., \& Sinnema, C. (2013). Emerging international trends in curriculum. In M. Priestley \& G. Biesta (Eds.) Reinventing the Curriculum: New Trends in Curriculum Policy and Practice (pp. 141-163). London: Bloomsbury.

Begg, A. (2005). Why curriculum matters to me. Curriculum Matters, 1, 1-11.

Biesta, G., \& Priestley, M (2013). A curriculum for the twenty-first century. In M. Priestley \& G. Biesta (Eds.) Reinventing the Curriculum: New Trends in Curriculum Policy and Practice (pp. 229-236). London: Bloomsbury. 


\section{Editorial}

Carpenter, V., \& Lee, D. (2010). Teacher education and the hidden curriculum of heteronormativity. Curriculum Matters, 6, 99-119.

Corbett, M. (2008). The Edumometer: The commodification of Education from Galton to PISA. Journal for Critical Education Policy Studies, 6(1), 352-378.

Edwards, S., Lambert, J., \& Tauroa, M. (2007). Epistemological voyaging: Thinking about Māori-centric curriculum. Curriculum Matters, 3, 139-147.

Fountain, G. (2008). Caught in between: How the scientific management of education in New Zealand made history history. Curriculum Matters, 8, 134-146.

Hannigan, B. (2013). The tightening noose: Scientific management and early childhood education. Curriculum Matters, 9, 120-138.

Hipkins, R. (2005). Learning to "be" in a new century: Reflections on a curriculum in transition. Curriculum Matters, 1, 71-85.

Mutch, C (2009). Curriculum: What, how and for whom? Curriculum Matters, 5, 1-4.

Olssen, M., Codd, J., \& O'Neill, A-M. (2004). Education Policy: Globalization, Citizenship and Democracy. London: Thousand Oaks.

Peters, M. (2002). Neoliberalism, postmodernity and the reform of education in Aotearoa/New Zealand. Access: Critical Perspective on Communication, Cultural and Policy Studies, 2l(1), 3-17.

Rutherford, G. (2009). Curriculum matters for all students? Understanding curriculum from perspectives of disabled students and teacher aides. Curriculum Matters, 5, 90-107.

Samu, T. W. (2011). Understanding the lines in the sand: Diversity, its discourses and building a responsive education system. Curriculum Matters, 7, 175-184.

Tallon, R. (2013). The challenges of the diverse media landscape when learning about current events in the social studies classroom. Curriculum Matters, 9, 29-45.

Young, M. (2014). What is curriculum and what can it do? The Curriculum Journal, 25(1), 7-13. 